University of Nebraska - Lincoln

DigitalCommons@University of Nebraska - Lincoln

USDA National Wildlife Research Center - Staff

Publications

U.S. Department of Agriculture: Animal and Plant Health Inspection Service

February 2005

\title{
Food Habits of Wolves in Relation to Livestock Depredations in Northwestern Minnesota
}

Andreas S. Chavez

Utah State University, Logan, chavez.102@osu.edu

Eric M. Gese

Utah State University, eric.gese@usu.edu

Follow this and additional works at: https://digitalcommons.unl.edu/icwdm_usdanwrc

Part of the Environmental Sciences Commons

Chavez, Andreas S. and Gese, Eric M., "Food Habits of Wolves in Relation to Livestock Depredations in Northwestern Minnesota" (2005). USDA National Wildlife Research Center - Staff Publications. 505. https://digitalcommons.unl.edu/icwdm_usdanwrc/505

This Article is brought to you for free and open access by the U.S. Department of Agriculture: Animal and Plant Health Inspection Service at DigitalCommons@University of Nebraska - Lincoln. It has been accepted for inclusion in USDA National Wildlife Research Center - Staff Publications by an authorized administrator of DigitalCommons@University of Nebraska - Lincoln. 


\title{
Food Habits of Wolves in Relation to Livestock Depredations in Northwestern Minnesota
}

\author{
ANDREAS S. CHAVEZ ${ }^{1}$ \\ Department of Forest, Range, and Wildlife Sciences, Utah State University, Logan 84322 \\ AND \\ ERIC M. GESE \\ U.S. Department of Agriculture, Wildlife Services, National Wildlife Research Center, \\ Department of Forest, Range, and Wildlife Sciences, Utah State University, Logan 84322
}

\begin{abstract}
Wolves (Canis lupus) have recolonized many areas of the Midwestern United States, prompting concern over the possible risk wolves may pose to livestock producers. To better understand the risks wolves may pose to livestock, we initiated a 3-y study examining the food habits of wolves in an agricultural area of northwestern Minnesota and their relation to depredation records of livestock losses in the same area. We collected 533 wolf feces during the non-winter seasons from 1997-1999. White-tailed deer (Odocoileus virginianus) was the most abundant food item $(39.2 \%)$ of all prey items for all 3 y combined. The deer component comprised both adult deer (26.9\%) and fawns (12.3\%). Muskrats (Ondatra zibethicus) were the second highest food item at $16.6 \%$. Moose (Alces alces), both adults $(13.0 \%)$ and calves $(0.6 \%)$, comprised $13.6 \%$ of the diet of wolves, followed by cattle (10.3\%), domestic pig $(4.4 \%)$, lagomorphs $(3.6 \%)$ and beaver (Castor canadensis; $2.1 \%$ ). During our 3-y study, eight head of livestock were officially reported as wolf depredations in the agricultural lands within the study area. The confirmed losses included one sheep, one injured cow, one blind cow and five calves. Even with very low deer and moose densities in the study area and a high preponderance of cattle in the area $(>1000$ head), the wolves in the area preyed mostly on native prey species.
\end{abstract}

\section{INTRODUCTION}

The historical range of the gray wolf (Canis lupus) included most of North America where wild ungulates were abundant (Carbyn, 1987). European settlement along with the introduction of domestic livestock into these areas altered the relationship between wolves and their native prey. Across the contiguous United States, domestic livestock replaced or coexisted with native ungulates. Wherever wolves and livestock coexisted, wolf depredations on livestock occurred (Young and Goldman, 1944; Gunson, 1983; Tompa, 1983; Fritts et al., 1992). As a result, the threat of wolf predation on domestic livestock became one of the leading reasons for humans to eradicate wolves throughout the contiguous United States. By the middle of the $20^{\text {th }}$ century, humans had successfully eradicated wolves from most of the contiguous United States, except for a single population in northeastern Minnesota.

The distribution of wolves in the contiguous United States began to increase during the latter half of the $20^{\text {th }}$ century due to increasing public empathy (Mech, 1995). This shift in public attitude prompted the U.S. Fish and Wildlife Service to protect the wolf in 1974 under the Endangered Species Act. In 1978 the Eastern Timber Wolf Recovery Team set forth guidelines for the recovery of wolves into parts of their former range in the upper Midwest. Wolves were able to rapidly recolonize most of the northern forests in the upper Midwest because these areas supported high deer populations that wolves used as their

${ }^{1}$ Present address: U.S. Fish and Wildlife Service, 6010 Hidden Valley Road, Carlsbad, California 92009 
primary prey (Fritts and Mech, 1981; Fuller, 1989). As most of the northern forest in Minnesota became saturated with wolf packs, wolves began establishing territories in peripheral semi-agricultural areas containing abundant livestock and native prey (Fuller et al., 1992; Berg and Benson, 1999). This population expansion of wolves into semi-agricultural areas culminated in increasing concerns from farmers about wolves killing livestock (Mech et al., 1988; Mech, 1995).

Little is known about the feeding ecology of wolves in a semi-agricultural area in the upper Midwestern U.S. Studying the food habits of wolves in a semi-agricultural system is necessary because it permits a more objective understanding of wolf behavior and ecology in relation to their prey (e.g., Mills, 1996). We examined the food habits of wolves in a semiagricultural area of northwestern Minnesota during the non-winter seasons. Our objective was to document the food habits of wolves during the time of year that livestock were grazing in pastures (non-winter seasons), document the number of livestock killed by wolves and investigate factors influencing wolf diet in an area with both native and domestic ungulates.

\section{METHODS}

Study area.-The study was conducted in the Red River Valley floodplain of northwestern Minnesota, along the northwest periphery of the gray wolf range in the Great Lakes region (Berg and Benson, 1999). Euro-American settlement has converted many of the native vegetation communities into agricultural lands; now the region is dominated by agricultural settlements mixed with intermittent woodlands, grasslands and marshes. The $1200 \mathrm{~km}^{2}$ study area, (hereafter referred to as Agassiz, $48^{\circ} 19^{\prime} \mathrm{N}, 95^{\circ} 59^{\prime} \mathrm{W}$ ) was comprised of an "island" of natural habitat, consisting of Agassiz National Wildlife Refuge and three adjoining state wildlife management areas (Elm Lake, Eckvoll and Mudlac Wildlife Management Areas) and its surrounding agricultural lands (Fig. 1). The study area was comprised of $53 \%$ cultivated lands, $20 \%$ wetlands, $10 \%$ brushlands, $10 \%$ forests (deciduous and coniferous) and $7 \%$ pasture and grasslands. The climate was characterized by short warm summers and long cold winters. Snow-cover was generally continuous from late November until April, restricting livestock grazing in pastures from May to early November. Moose (Alces alces), white-tailed deer (Odocoileus virginianus), beaver (Castor canadensis), muskrats (Ondatra zibethicus) and eastern cottontail rabbits (Sylvilagus floridanus) represented the main native prey available to wolves.

Food habit analysis. - Wolf food habits were determined by fecal analysis. Wolf feces were collected every $2 \mathrm{wk}$ on standardized routes within our study area during spring, summer and autumn of 1997-1999. Feces were identified based on their shape, size and odor in order to distinguish them from non-wolf feces (Weaver and Fritts, 1979). Feces were placed in nylon stockings (mesh size $<0.25 \mathrm{~mm}^{2}$ ) and washed in a washing machine with bleach to reduce exposure to hydatid tapeworms (Echinococcus granulosus). Feces were then air-dried and examined macroscopically for prey remains. Hairs and solid fragments (i.e., bones, teeth) were segregated by species. In instances where macroscopic inspection was not possible for prey identification, negative impressions of hair cuticular scale patterns were examined under a compound microscope (Adjoran and Kolenosky, 1969). In addition, a reference collection of hairs and their cuticular scale impressions of all potential prey items were made to help in microscopic prey identification. A visual estimate, to the nearest

FIG. 1.-Location of Agassiz NWR and State WMA's, wolf territory boundaries and livestock pastures during (A) 1998 and (B) 1999, northwestern Minnesota 
A

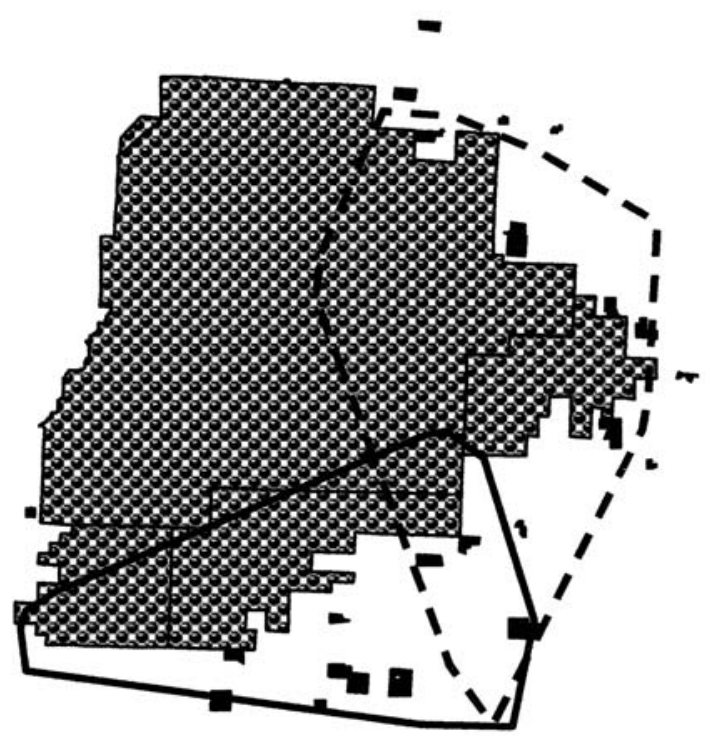

B

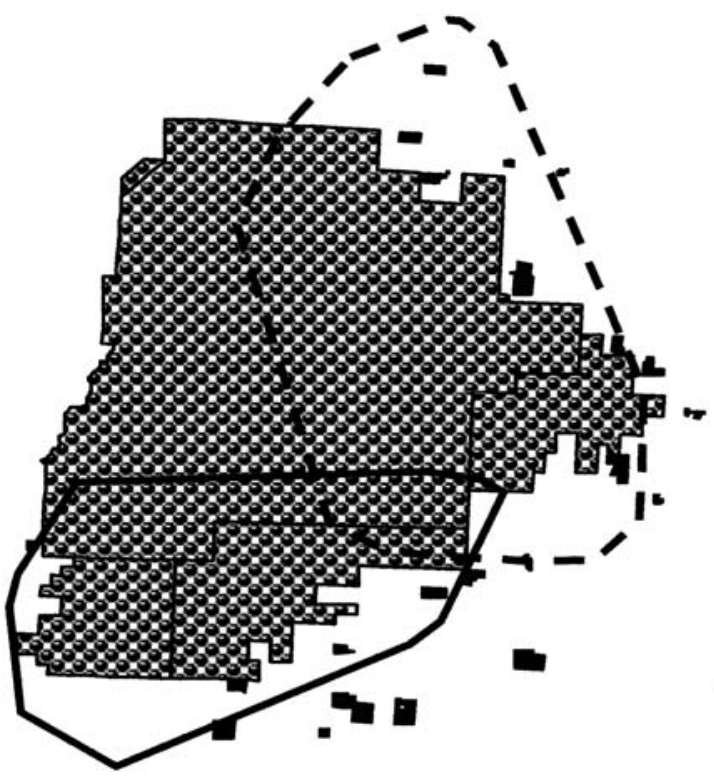


$5 \%$, of the percent volume of each prey species was made for each feces. We did not use frequency of occurrence of each prey species because small prey is often over-represented by this technique (Weaver and Hoffman, 1979).

Prey estimates.-We used different methods for estimating native ungulate and domestic livestock abundance. We used data from the U.S. Fish and Wildlife Service's mid-winter aerial surveys for deer and moose. The survey area included Agassiz NWR and the adjacent state wildlife management areas; the surrounding agricultural lands were not surveyed. Surveys were flown at $75 \mathrm{~m}$ above ground. A sightability correction factor was assigned for population estimates for each species. The size of the cattle population was determined by requesting numbers from each cattle producer $(\mathrm{n}=27)$ within $4.8 \mathrm{~km}$ of the boundary of the refuge and its adjacent state lands. We did not estimate sheep or domestic pig densities because they occurred in very small numbers (two sheep operations and one domestic pig operation) and because domestic pigs were not vulnerable to wolf predation (they were all enclosed within a barn). However, wolves did scavenge dead pigs at the farm's open-carcass dump.

Livestock depredations.-During the 3-y of our study, wolf depredation events in the agricultural areas within our study area were documented by reports from U.S. Department of Agriculture-Animal and Plant Health Inspection Service-Wildlife Services (WS) wolf specialists. In Minnesota, farmers may contact either a Minnesota Department of Natural Resources (MDNR) conservation officer or a WS wolf specialist for verification of claims of potential wolf depredations on livestock (Fritts et al., 1992). This action determines if farmers receive compensation for animals killed by wolves.

\section{RESULTS}

A total of 533 wolf feces were collected during the non-winter seasons from 1997-1999. White-tailed deer was the most abundant food item for all 3 y combined (Table 1). The deer component in the feces comprised both adult deer $(26.9 \%)$ and fawns $(12.3 \%)$. Muskrats were the second highest food item by volume for wolves, followed by adult moose $(13.0 \%)$ and moose calves $(0.6 \%)$, cattle, domestic pig, lagomorphs and beaver. Various birds, rodents, insects and vegetation were minor components of the diet, totaling $10.6 \%$ by volume of all other prey items identified. There was some minor annual variation in the role of different prey species in the wolves during 1997-1999 (Table 1). In 1997 the percent volumes of muskrat and deer remains in the wolves diet were very similar. During the following $2 \mathrm{y}$, deer was the main prey item in the wolves diet. Furthermore, the percent volumes of muskrat, moose and cattle remains in the diet of wolves were similar during 1998 and 1999. The role that domestic pig played in the diet of wolves declined during the $3 \mathrm{y}$ (Table 1 ).

There were fluctuations in the percent volume of deer, moose and muskrat remains in the diet of wolves at 2-wk intervals during the non-winter months (Fig. 2). Decreases of deer in the diet of wolves were often complemented by increases in muskrats, but less by moose. Similarly, deer and muskrat were represented more consistently than moose in the diet of wolves at 2-wk intervals during spring, summer and autumn. Also, small sample sizes of scats across the 2-week time periods likely contributed to the variation observed.

During the period of our study, the deer population at Agassiz was at its lowest levels in the past 30 y but slightly increasing (G. Huschle, unpubl. data). Winter surveys of 1996-1997 and 1997-1998 estimated the deer population to be $455 \pm 165$ deer (90\% confidence interval) and $432 \pm 226$ deer, respectively. In 1999 the deer population increased slightly to $504 \pm 190$ deer. These numbers were considered dramatically low compared to the past 30 years when deer population estimates were never lower than 1172 deer (confidence intervals were not calculated before 1995); in the winter of 1993-1994 the population was estimated to be 2670 deer. Similarly, the moose population during the period of our study 
TABLE 1.-Percent volume of food items in the wolves' diet over 3 y during the non-winter months, northwestern Minnesota, 1997-1999. Numbers in parentheses represent the volume of young-of-theyear in the diet for that prey species

\begin{tabular}{lcccc}
\hline \hline \multicolumn{1}{c}{ Food item } & 1997 & 1998 & 1999 & All years \\
\hline Odocoileus virginianus & $\mathrm{N}=199$ & $\mathrm{~N}=101$ & $\mathrm{~N}=232$ & $\mathrm{~N}=532$ \\
Ondatra zibethicus & $23.0(13.6)$ & $49.1(13.2)$ & $48.7(10.7)$ & $39.2(12.3)$ \\
Alces alces & 23.5 & 13.0 & 12.3 & 16.6 \\
Cattle & $15.3(1.1)$ & $14.5(0.0)$ & $12.0(0.4)$ & $13.6(0.6)$ \\
Pig & 8.0 & 8.8 & 12.8 & 10.3 \\
Sylvilagus floridanus & 8.8 & 4.2 & 0.8 & 4.4 \\
Castor canadensis & 4.2 & 4.5 & 2.6 & 3.6 \\
Bird spp. & 2.7 & 0.0 & 2.5 & 2.1 \\
Microtus spp. & 2.8 & 2.4 & 0.8 & 1.8 \\
Other & 0.5 & 1.5 & 2.4 & 1.5 \\
Marmota monax & 2.5 & 0.1 & 0.9 & 1.4 \\
Mephitis mephitis & 1.3 & 0.2 & 1.6 & 1.2 \\
Procyon lotor & 1.7 & 0.0 & 0.9 & 1.0 \\
Insects & 1.2 & 0.3 & 1.2 & 1.0 \\
Vegetation & 2.6 & 0.0 & 0.0 & 0.8 \\
Mustela vison & 1.0 & 1.0 & 0.4 & 0.3 \\
Vulpes vulpes & 0.6 & 0.1 & 0.0 & 0.1 \\
Geomys bursarius & 0.2 & 0.0 & 0.0 & 0.0 \\
\hline
\end{tabular}

${ }^{\mathrm{a}}$ Other includes Canis lupus, Martes pennanti, Taxidea taxus and egg

was low and considered to be declining (G. Huschle, unpubl. data). Winter surveys of 19961997, 1997-1998 and 1998-1999 estimated the moose population to be $115 \pm 44$ moose (90\% confidence interval), $107 \pm 88$ moose and $65 \pm 47$ moose, respectively. These numbers were considered low because the winter moose population estimate was never lower than 205 moose (1989-1990) during the past $30 \mathrm{y}$; in the winter of 1992-1993 the population was estimated to be 244 moose. We estimated 1000 head of adult cattle were in the agricultural lands within the study area.

From 1997 to 1999 there were eight officially reported wolf depredation incidents on livestock in the agricultural lands within $6.4 \mathrm{~km}$ of Agassiz. The livestock confirmed to have been killed by wolves during our study consisted of one sheep, one injured cow, one blind cow and five calves. Depredation events coincided with the presence of cattle remains in the wolves feces (Fig. 3), but cattle remains were also found in the wolves' feces during other times. Scavenging of carcasses contributed to the presence of cattle unrelated to depredation events and illustrates the limitations of fecal analysis to determine predation patterns.

\section{Discussion}

In North America, wolves generally are restricted to areas where ungulates are available as prey. The smallest ungulate species generally is represented the most in the diet of wolves when wolves live in systems containing multiple ungulate species and availability of the smaller ungulate is high (e.g., Fritts and Mech, 1981; Dale et al., 1995; Spaulding et al., 1998; Kunkel et al., 1999). Several studies in areas where white-tailed deer and moose coexisted with wolves reported deer were represented the most in the diet of wolves (e.g., Van Ballenberghe et al., 1975; Fritts and Mech, 1981; Fuller, 1989). Reasons for this pattern are not well understood, but may be due to the smaller ungulates being more vulnerable to wolf 


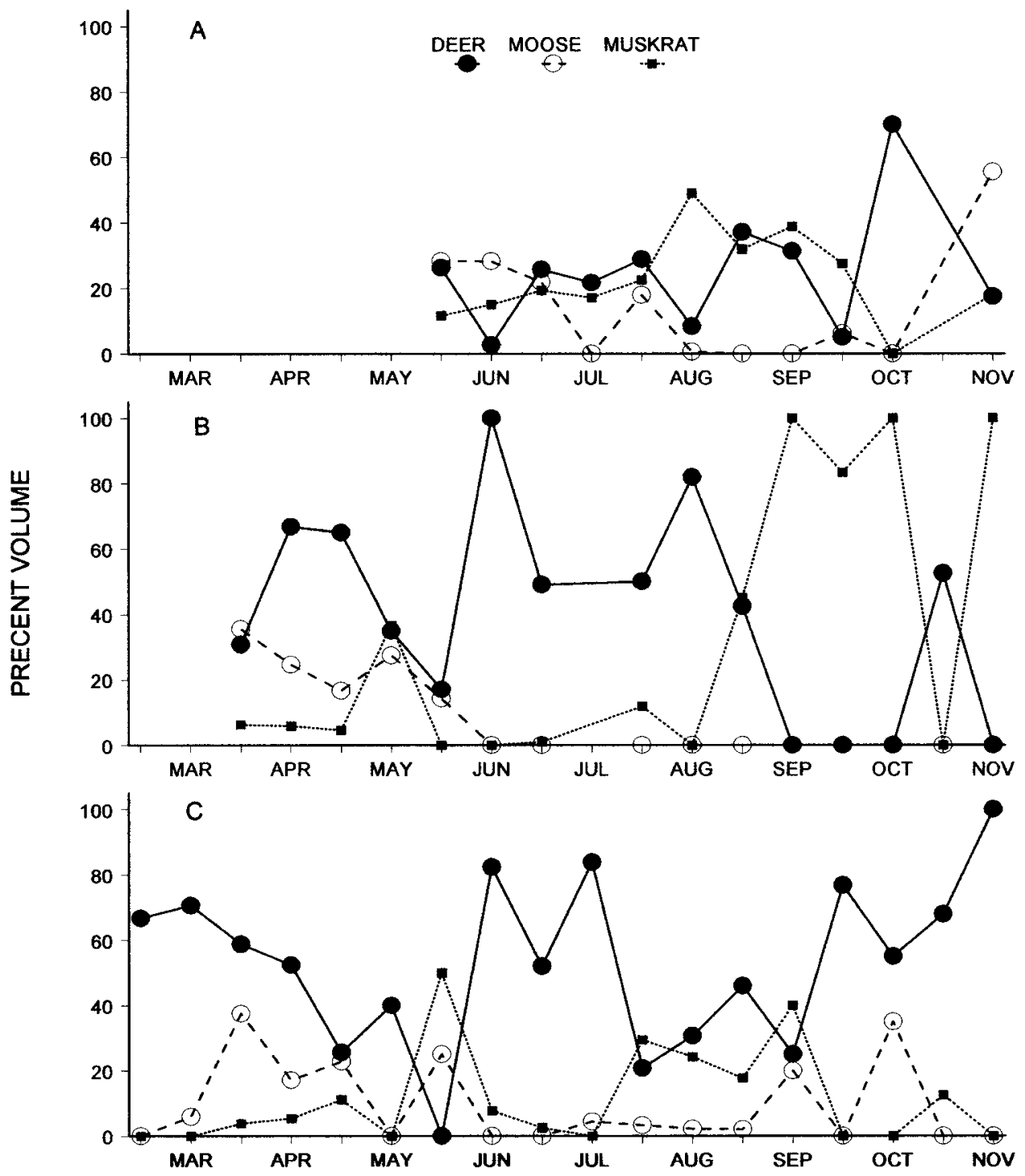

FIG. 2.-Percent volume of deer, moose and muskrat in the diet of wolves at 2-wk intervals during (A) 1997, (B) 1998 and (C) 1999, northwestern Minnesota

predation (Mech, 1970). Our study site primarily contained three ungulate species: whitetailed deer, moose and cattle. Similar to other studies in Minnesota (Van Ballenberghe et al., 1975; Fritts and Mech, 1981; Fuller, 1989), white-tailed deer (the smallest ungulate) were the most common food item by percent volume in the diet of wolves during the non-winter seasons. Muskrat and moose were the next most common food items, followed by cattle, domestic pig, lagomorphs and beaver. The remainder of the diet was comprised of various bird species, rodents, insects and vegetation. 


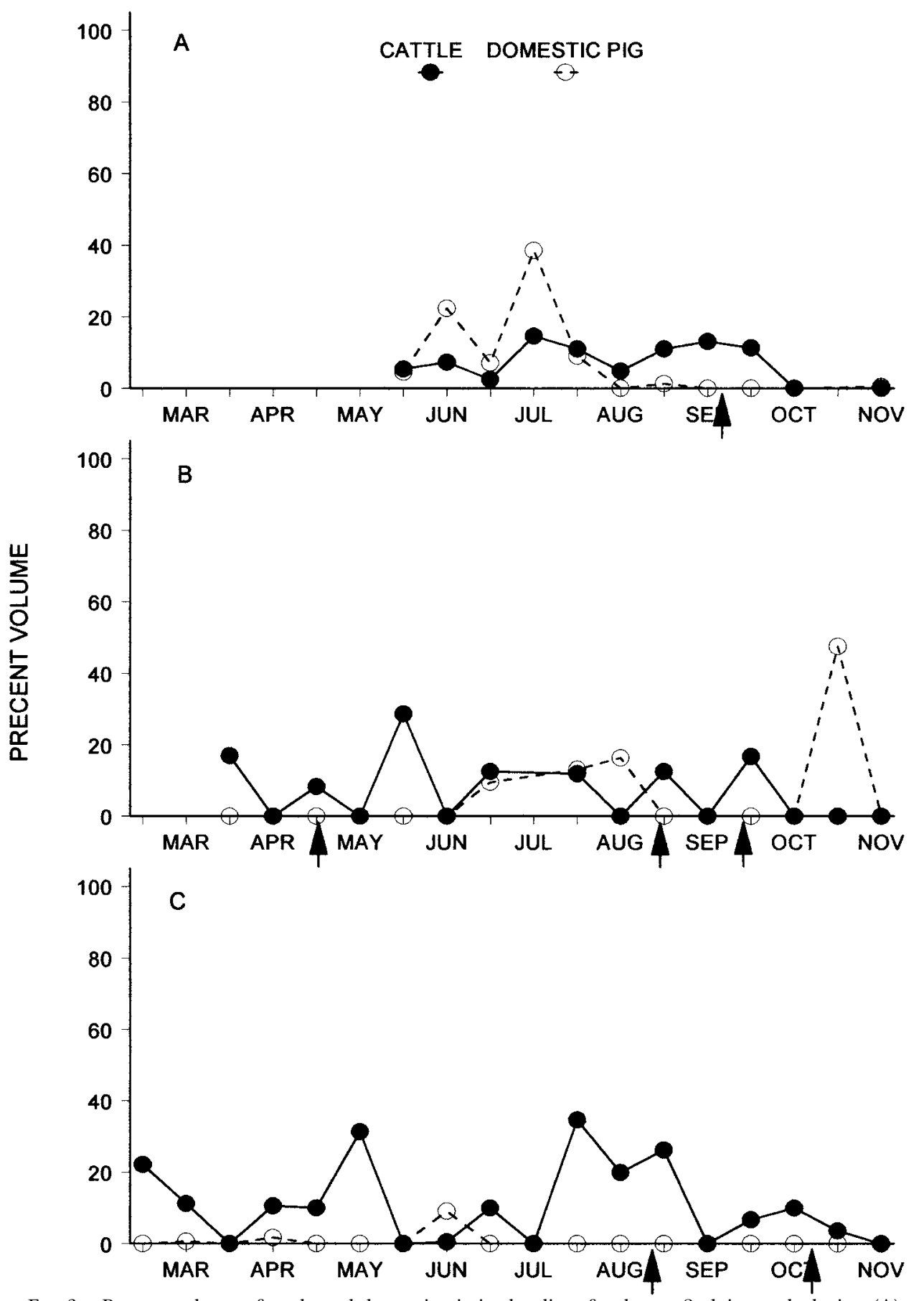

FIG. 3.-Percent volume of cattle and domestic pig in the diet of wolves at 2-wk intervals during (A) 1997, (B) 1998 and (C) 1999, northwestern Minnesota. Arrows indicate the dates of confirmed wolf depredation events on livestock (event in 1997 involved a sheep, events in 1998 and 1999 involved cattle) 
Wolves possess plasticity in their foraging capabilities and can compensate for changes in prey abundance, distribution or behavior by switching to other prey species (Bergerud, 1983; Potvin et al., 1988). Our study occurred when both deer and moose populations were at extremely low numbers due to two consecutive severe winters before our study. Furthermore, deer densities (1.3-1.5 deer $\left./ \mathrm{km}^{2}\right)$ in our study area were the lowest reported in Minnesota where deer are the primary prey of wolves (Van Ballenberghe et al., 1975; Fritts and Mech, 1981; Fuller, 1989). At such low densities, we expected deer to be more difficult for wolves to hunt because of the lower encounter rate and their presumed better physiological condition due to both lower intraspecific competition and mild winters. In addition, the moose population was in the midst of a long-term decline due primarily to severe winters and parasitism. However, at a time of very low deer and moose numbers, wolves did not switch to cattle as a major food item. Wolves failing to switch to alternate prey also were reported in other multi-ungulate prey systems (Van Ballenberghe et al., 1975; Potvin et al., 1988; Dale et al., 1995).

There may be several reasons for why wolves did not switch to cattle. One may argue control actions following depredations prevented wolves from preying on cattle because it either killed the wolves responsible for killing livestock or deterred surviving wolves from going near pastures. However, we believe control actions did not influence wolf behavior because surviving wolves were found to be visiting the same or other cattle pastures later during the same year (Chavez, 2002). Wolves possibly did not prey on cattle more often because there were still enough native ungulates, even though deer and moose were at very low densities. Studies in Europe indicated wolves selected livestock when native ungulate densities were extremely low (Cuesta et al., 1991; Vos, 2000). Researchers from these studies recommended introducing native ungulates into this system to reduce the wolves' reliance on livestock. In other areas, where native ungulates were abundant and coexisted with livestock, wolves fed primarily on native ungulates, and occasionally killed livestock (e.g., Salvador and Abad, 1987; Meriggi et al., 1991; Smietana and Klimek, 1993).

It was also possible the hyper-abundance of secondary prey species (beavers, hares, muskrats) during the non-winter months, as well as the availability of domestic livestock carrion, dampened the need for wolves to switch to cattle. Numerous studies demonstrated secondary prey items as being necessary dietary components for wolves during spring, summer and autumn (e.g., Van Ballenberghe et al., 1975; Fritts and Mech, 1981; Fuller, 1989). Furthermore, studies also demonstrated that the amount of secondary prey in the diet of wolves increased during periods of low ungulate densities (Voigt et al., 1976; Messier and Crête, 1985; Forbes and Theberge, 1996). Secondary food items also seemed necessary for wolves during our study as muskrats were the second most common food item in the diet of wolves. This is the first study to document muskrats as a common and consistent food item for wolves. However, the ratio of digestible and undigestible materials changes with size of the prey item. Thus, the relative contribution of large prey items (moose, cattle, deer) to the energy budget of wolves may be higher than fecal analysis would demonstrate.

Minimal amount of wolf depredations on livestock also may reflect hunting strategies of wolves during non-winter months. Because secondary prey and neonatal ungulates are widely available during this time of year, wolves may not hunt in large packs as they do in winter. Thus, wolves may not be as capable of killing adult cattle when traveling in smaller groups. However, calves should still be vulnerable but were rarely killed. Therefore, changes in group size and hence hunting strategy may not have contributed to the minimal cattle predation we observed during the study.

The availability of carrion may have been a factor reducing the need for wolves to prey on cattle more often. Wolves scavenging on carrion was reported on a few occasions from local 
farmers. Some of these dates coincided with the dates cattle remains were discovered in the feces of wolves, which means that not all of the cattle found in feces was from wolf depredations. Our findings illustrate the disadvantage of fecal analysis in its inability to distinguish between predation events and scavenging of animal remains. Thus, the actual risk to livestock may be overestimated using fecal sampling alone when scavenging of carcasses occurs and is not indicative of actual wolf predation.

We also were aware of wolves feeding on domestic pig carcasses because of frequent observations of radioed wolves visiting a pig carcass dump. Because this was the only domestic pig operation in the area, we were certain pig remains found in the diet of wolves resulted entirely from this carcasses dump. When the producer ceased dumping pig carcasses at the end of 1998, the wolves were never found visiting this area again and pig was virtually non-existent in the diet of wolves thereafter. Moreover, wolves scavenging on moose likely explained most of the occurrence of moose in the diet of wolves because a concurrent moose study in our area did not report a single wolf predation event on an adult cow moose (E. Cox, unpubl. data). Wolves scavenging on moose carcasses during the summer also was reported in other studies (Fritts and Mech, 1981; Peterson et al., 1984; Potvin et al., 1988; Forbes and Theberge, 1996).

Anti-predator defense was possibly another factor discouraging wolves from preying on cattle more often. Anti-predator defense varies widely among ungulate species. Deer occasionally injure and even kill wolves when attacked (Nelson and Mech, 1985; Mech and Nelson, 1990), but generally, they stand alert when unthreatened and rapidly flee when chased or closely approached by wolves (Nelson and Mech, 1993). In contrast, moose are a more formidable and dangerous prey for wolves to kill (e.g., Mech and Nelson, 1990; Weaver et al., 1992). Wolves did not kill moose more frequently during our study even when many moose in the area were debilitated with brainworm (Parelaphostrongylus tenuis) which causes behaviors such as aimless walking in circles, frequent stumbling, poor coordination or balance, and weakness or paralysis of their legs (Anderson, 1964).

Conversely, cattle are perceived as having limited self-defense capabilities because of their domestication (Mech, 1970). However, cattle may possess more defensive capabilities because some farmers reported witnessing adult cattle chasing away wolves, similar to reports in the northern Rocky Mountains (J. Fontaine, U.S. Fish and Wildlife Service, pers. comm.) and Italy (Meriggi et al., 1991). Furthermore, all of the livestock killed by wolves were restricted to very vulnerable individuals (calves, diseased adults, sheep), indicating healthy cattle were able to protect themselves from wolves.

Currently, reports of wolf depredations on livestock in Minnesota are relatively infrequent $(<1 \%$ of farms are affected by confirmed wolf depredations annually: Paul, 1999). This is consistent with our finding that wolves living in areas with livestock were primarily utilizing native prey. One way to eliminate wolf-livestock conflicts at Agassiz would be to eliminate wolves. This idea has been voiced since this area is considered a "no-wolf" zone under the Eastern Timber Wolf Recovery Plan (U.S. Fish and Wildlife Service, 1978; Mech, 1998). However, as the wolf population has persisted in this area since the early 1980s and there is a source of dispersing wolves from nearby populations, eliminating wolves from this area is unlikely (Mech, 1998). Livestock producers can take precautions for protecting the most vulnerable stock as a means of reducing wolf-livestock conflicts. In addition, management for healthy native prey populations should help reduce the likelihood of wolves preying on livestock.

Acknowledgments.-Logistical and financial support provided by the U.S. Fish and Wildlife ServiceAgassiz National Wildlife Refuge and the U.S. Department of Agriculture, Wildlife Services, National 
Wildlife Research Center, Logan Field Station at Utah State University. We thank M. Young, K. Frykmen, M. Hackett, C. Hill, E. Peacock, S. Naftal, A. Hendel, J. Sikich, S. Richter, S. Graham, M. Clark, R. Callan, E. Joyce, L. Schutte, J. Muntifering and E. Bergman for field assistance; M. Anderson, G. Huschle, S. Wockenfuss and D. Van Eps of Agassiz National Wildlife Refuge for logistical and technical support; and B. Gilbert and R. Krannich for reviews of the manuscript. Research protocols were approved by the Institutional Animal Care and Use Committee at Utah State University.

\section{Literature Cited}

Adorjan, A. S. and G. B. Kolenosky. 1969. A manual for the identification of hairs of selected Ontario mammals. Res. Rep. (Wildl.), Ont. Dep. Lands For., 90:1-64.

Anderson, R. C. 1964. Neurologic disease in moose infected experimentally with Pneumstrongylus tenuis from white-tailed deer. Pathologia Veterinaria, 1:289-332.

BerG, W. E. ANd S. Benson. 1999. Updated wolf population estimate for Minnesota, 1997-1998. Minn. Dep. Nat. Resour., Grand Rapids, Minnesota.

Bergerud, A. T. 1983. Prey switching in a simple ecosystem. Sci. Am., 249:130-141.

CARbYn, L. N. 1987. Gray wolf and red wolf, p. 379-393. In: M. Novak, G. A. Baker, M. E. Obbard and B. Malloch (eds.). Wild furbearer management and conservation in North America. Ontario Trappers Association and the Ministry of Natural Resources, Toronto, Ontario, Canada.

Chavez, A. S. 2002. Assessing the potential, actual, and perceived risk that gray wolves, Canis lupus, pose to livestock in northwestern Minnesota. M.S. Thesis, Utah State University, Logan, Utah. 118 p.

Cuesta, L., F. Barcena, F. Palacios and S. Reig. 1991. The trophic ecology of the Iberian Wolf (Canis lupus signatus, Cabrera, 1907). A new analysis of stomach's data. Mammalia, 55:239-254.

Dale, B. W., L. G. Adams And R. T. Bowyer. 1995. Winter wolf predation in a multiple ungulate prey system, Gates of the Arctic National Park, Alaska, p. 223-230. In: L. N. Carbyn, S. H. Fritts and D. R. Seip (eds.). Ecology and conservation of wolves in a changing world. Occas. Pub. 35, Can. Circumpolar Inst., Univ. Alberta, Edmonton, Alberta.

Forbes, G. J. ANd J. B. Theberge. 1996. Response by wolves to prey variation in central Ontario. Can. J. Zool., 74:1511-1520.

FritTs, S. H. AND L. D. Mech. 1981. Dynamics, movements, and feeding ecology of a newly protected wolf population in northwestern Minnesota. Wildl. Monogr., 80:1-79.

, W. J. PAul, L. D. MECH and D. P. Scott. 1992. Trends and management of wolf-livestock conflicts in Minnesota. U.S. Fish Wildl. Serv., Resour. Pub., 181:1-27.

Fuller, T. K. 1989. Population dynamics of wolves in north-central Minnesota. Wildl. Monogr., 105:1-41. , W. E. Berg, G. L. RAdDE, M. S. LenarZ ANd G. B. Joselyn. 1992. A history and current estimate of wolf distribution and numbers in Minnesota. Wildl. Soc. Bull., 20:42-55.

Gunson, J. R. 1983. Status and management of wolves in Alberta, p. 25-29. In: L. N. Carbyn (ed.). Wolves in Canada and Alaska: their status, biology, and management. Can. Wildl. Serv. Rep. Ser, 45: $1-135$.

Kunkel, K. E., T. K. Ruth, D. H. Pletscher and M. G. Hornocker. 1999. Winter prey selection by wolves and cougars in and near Glacier National Park, Montana. J. Wildl. Manage., 63:901-910.

Mech, L. D. 1970. The wolf: the ecology and behavior of an endangered species. Natural History Press, Garden City, New York. 384 p.

1995. The challenge and opportunity of recovering wolf populations. Cons. Bio., 9:270-278.

1998. Estimated costs of maintaining a recovered wolf population in agricultural regions of Minnesota. Wildl. Soc. Bull., 26:817-822.

and M. E. Nelson. 1990. Evidence of prey-caused mortality in three wolves. Am. Mid. Nat., 123:207-208.

- S. H. FritTs AND W. J. Paul. 1988. Relationship between winter severity and wolf depredations on domestic animals in Minnesota. Wildl. Soc. Bull., 16:269-272.

Meriggi, A., P. Rosa, A. Brangi and C. Matteucci. 1991. Habitat use and diet of the wolf in northern Italy. Acta Theriologica, 36:141-151.

Messier, F. And M. CRete. 1985. Moose-wolf dynamics and the natural regulation of moose populations. Oecologia, 65:503-512. 
Mills, M. G. L. 1996. Methodological advances in capture, census, and food-habits studies of large African carnivores, p. 223-242. In: J. L. Gittleman (ed.). Carnivore behavior, ecology, and evolution, Vol. 2. Comstock Publishing Associates, Cornell University Press, Ithaca, New York.

Nelson, M. E. AND L. D. MeCh. 1985. Observation of a wolf killed by a deer. J. Mammal., 66:187-188.

AND —. 1993. Prey escaping wolves, Canis lupus, despite close proximity. Can. Field-Nat., 107:245-246.

PAuL, W. J. 1999. Wolf depredation on livestock in Minnesota, annual update of statistics-1998. U.S. Department of Agriculture, Animal and Plant Health Inspection Service, Wildlife Services. Grand Rapids, Minnesota.

Peterson, R. O., J. D. Woolington and T. N. Bailey. 1984. Wolves of the Kenai Peninsula, Alaska. Wildl. Monogr., 88:1-52.

Potvin, F., H. Jolicoeur and J. Huot. 1988. Wolf diet and prey selectivity during two periods for deer in Quebec: decline versus expansion. Can. J. Zool., 66:1274-1279.

Salvador, A. ANd P. L. Abad. 1987. Food habits of a wolf population (Canis lupus) in Leon Province, Spain. Mammalia, 51:45-52.

Smietana, W. and A. Klimek. 1993. Diet of wolves in the Bieszczady Mountains, Poland. Acta Theriologica, 38:245-251.

Spaulding, R. L., P. R. Krausman and W. B. Ballard. 1998. Summer diet of gray wolves, Canis lupus, in northwestern Alaska. Can. Field-Nat., 112:262-266.

Tompa, F. S. 1983. Status and management of wolves in British Columbia, p. 20-24, In: L. N. Carbyn (ed.). Wolves in Canada and Alaska: their status, biology, and management. Canadian Wildlife Service Report Series 45.

U.S. Fish and Wildlife Service. 1978. Recovery plan for the eastern timber wolf. Prepared by the Eastern Timber Wolf Recovery Team, U.S. Government Printing Office, Washington, D.C.

Van Ballenberghe, V., A. W. Erickson and D. Byman. 1975. Ecology of the timber wolf in northeastern Minnesota. Wildl. Monogr, 43:1-43.

Voigt, D. R., G. B. Kolenosky and D. H. Pimlott. 1976. Changes in summer foods of wolves in central Ontario. J. Wildl. Manage., 40:663-668.

Vos, J. 2000. Food habits and livestock depredation of two Iberian wolf packs (Canis lupus signatus) in the north of Portugal. J. Zool. (London), 251:457-462.

Weaver, J. L. and S. H. Fritts. 1979. Comparison of coyote and wolf scat diameters. J. Wildl. Manage., 43:786-788.

AND S. W. Hoffman. 1979. Differential detectability of rodents in coyotes scats. J. Wildl. Manage., 43:783-786.

C. Arvidson and P. Wood. 1992. Two wolves, Canis lupus, killed by a moose, Alces alces, in Jasper National Park, Alberta. Can. Field-Nat., 106:126-127.

Young, S. P. AND E. A. Goldman. 1944. The wolves of North America. Dover, New York. 